\title{
Computational studies on energetic properties of nitrogen-rich energetic materials with ditetrazoles
}

\author{
LI XIAO-HONG ${ }^{\mathrm{a}, \mathrm{b}, *}$ and ZHANG RUI-ZHOU ${ }^{\mathrm{a}}$ \\ ${ }^{a}$ College of Physics and Engineering, Henan University of Science and Technology, Luoyang 471 003, China \\ ${ }^{b}$ Luoyang Key Laboratory of Photoelectric Functional Materials, Henan University of Science and \\ Technology, Luoyang 471 003, China \\ e-mail: lorna639@126.com
}

MS received 3 October 2013; revised 19 April 2014; accepted 26 April 2014

\begin{abstract}
Based on the full optimized molecular geometric structures at B3LYP/6-311++G**level, the densities $(\rho)$, heats of formation (HOFs), detonation velocities (D) and pressures (P) for a series of ditetrazoles derivatives, were investigated to look for high energy density materials (HEDMs). The results show that the influence of different substituted groups on HOFs has the order of $-\mathrm{N}_{3}>-\mathrm{CN}>-\mathrm{NH}_{2}>-\mathrm{NO}_{2}>-\mathrm{NF}_{2}>-\mathrm{ONO}_{2}>-\mathrm{H}>-$ $\mathrm{CH}_{3}>-\mathrm{CF}_{3}$. The introduction of $-\mathrm{CF}_{3}$ groups is more favourable for increasing the density and the introduction of $-\mathrm{CH}_{3}$ groups is not favourable for increasing the density. In addition, all the series combined with $-\mathrm{NF}_{2}$ group except $\mathrm{B}-\mathrm{NF}_{2}$ all have higher densities, larger $\mathrm{D}$ and $\mathrm{P}$. $\mathrm{F}-\mathrm{NF}_{2}$ may be regarded as the potential candidates of HEDMs because of the largest detonation velocity and pressure among these derivatives. The energy gaps between the HOMO and LUMO of the studied compounds are also investigated.
\end{abstract}

Keywords. Density functional theory; heat of formation; detonation performance; energy gap; ditetrazoles derivatives

\section{Introduction}

Five- or six-membered nitrogen-containing heterocycles are promising candidates for high-energy density materials (HEDMs) both theoretically and experimentally ${ }^{1-4}$ due to their novel properties including high density, ${ }^{5,6}$ high positive heats of formation $(\mathrm{HOFs})^{7,8}$ and high thermal stability. ${ }^{1,9}$ As a kind of high nitrogen-contented heterocyclic compounds, azoles and their derivatives have been intensively studied due to their high percentage of nitrogen, low carbon and desirable stability, which make them of interest for the synthesis of high energetic materials. ${ }^{10-13} \mathrm{Li}$ et al. ${ }^{14-16}$ have performed many studies on nitrogenrich energetic compounds on the basis of tetrazine, triazole and their derivatives. Alexander et al. ${ }^{17}$ synthesized a series of nitrogen-rich triazolate salts by using triazole derivatives. Pasupala et al. ${ }^{18}$ investigated $1,3,4,5$ tetranitropyrazole as potential primary explosives. All these compounds have good properties and offer the potential for application as energetic materials.

*For correspondence
Generally, the introduction of nitro groups for tetrazine displays poor thermal and chemical stability, but the introduction of nitro groups for furazan ring provides a better oxygen balance. In addition, the introduction of an amino group is one of the simplest means to improve the thermal stability of an energetic material. If some groups such as $-\mathrm{CN},-\mathrm{NH}_{2},-\mathrm{N}_{3}$ groups are incorporated to the tetrazole, what changes will the properties of the new energetic materials produce?

Properties are often manipulated by making structural modifications. Owing to the difficulties in the synthesis of the molecules under consideration, theoretical studies become an effective way to design high-energy density compounds. Theoretical studies can not only screen candidate compounds thereby avoiding expensive experimental tests, but can also help understand the relationships between molecular structure and properties, which in turn can help design better and more efficient laboratory tests.

Coupling two heterocyclic compounds together provides a good way to obtain explosive with higher nitrogen content and better properties. Zhang et al. ${ }^{19}$ investigated the thermal stability, detonation velocities and pressures of the substituted carbon-bridged diiminotetrazoles. Shreeve et al. ${ }^{20}$ presented that nitroiminotetrazoles linked by $-\mathrm{CH}_{2}-\mathrm{CH}_{2}$ - have very high positive 
HOFs and good detonation properties. Tao et al. ${ }^{21}$ studied the HOFs, thermal stability and detonation properties for a series of nitrogen-bridged 1,2,4,5ttrazine, furazan-, and $1 \mathrm{H}$-tetrazole-based polyheterocyclic compounds. Zhang et al. ${ }^{22}$ investigated the energetic substituted carbon- and nitrogen-bridged difurazans. A considerable number of studies have confirmed that high nitrogen compounds with $\mathrm{N}$ chain perform well as energetic compounds.

Based on the previous studies, we theoretically investigated the HOFs, energetic properties and thermal stability of a series of bridged ditetrazoles with the linkage $-\mathrm{N}-\mathrm{N}$ - and substituent groups $\left(-\mathrm{CF}_{3},-\mathrm{CH}_{3},-\mathrm{CN},-\mathrm{N}_{3}\right.$, $\mathrm{NF}_{2},-\mathrm{NO}_{2},-\mathrm{ONO}_{2}$ ) by using density function theory (DFT) (figure 1). Our main purpose is to investigate the important role of substituents in the design of efficient high-energy density compounds.

\section{Computational Methods}

The DFT-B3LYP method ${ }^{23,24}$ in combination with the $6-311++\mathrm{G}^{* *}$ basis set is widely used in many investigations, ${ }^{25-27}$ and could give reasonable energies, molecular structures and infrared vibrational frequencies. In this paper, 1,2,4,5-tetrazine based derivatives were fully optimized to obtain their molecular geometries and electronic structures. Vibrational analysis was performed thereafter at the same level with the Gaussian03 program package. ${ }^{28}$

The atomization reaction or isodesmic reaction method can be used to obtain the standard HOF at $298.15 \mathrm{~K}$. In this paper isodesmic reaction method was used. ${ }^{29,30}$ The accuracy of HOF obtained theoretically is conditioned by the reliability of HOF of the reference compounds. The HOFs for the title compounds can be derived from the following isodesmic reactions:

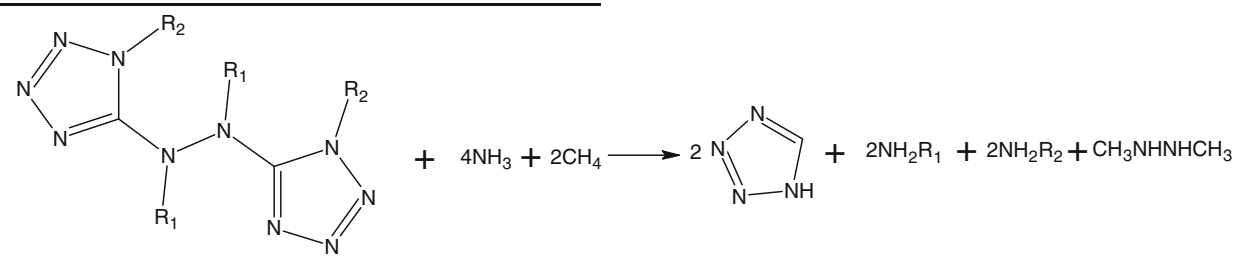

In these designed reactions, the basic structural unit of the tetrazole skeleton is kept invariable, and the big molecules are changed into small ones too. For the isodesmic reactions (1), heat of reaction $\Delta H_{298}$ at $298 \mathrm{~K}$ can be calculated from the following equation:

$$
\Delta H_{298}=\sum \Delta H_{f, P}-\sum \Delta H_{f, R}
$$

Where $\Delta H_{f, P}$ and $\Delta H_{f, R}$ are the HOFs of products and reactants at $298 \mathrm{~K}$, respectively. The HOFs of the title compounds can be figured out when the heat of reaction $\Delta H_{298}$ is known. The HOFs at $298.15 \mathrm{~K}$ can be calculated from the following equation:

$$
\begin{aligned}
\Delta H_{298.15 K} & =\Delta E_{298.15 K}+\Delta(P V) \\
& =\Delta E_{0}+\Delta Z P E+\Delta H_{T}+\Delta n R T \\
& =\sum_{\text {product }} \Delta H_{f}^{0}-\sum_{\text {reactan } t} \Delta H_{f}^{0}
\end{aligned}
$$

Where $\triangle E_{0}$ and $\triangle Z P E$ are the total energy difference and the zero-point energy difference between products and reactants at $0 \mathrm{~K}$, respectively; $\Delta H_{T}$ is the changes in thermal correction to enthalpies between products and reactants; $\sum_{\text {product }} \Delta H_{f}^{0}$ and $\sum_{\text {reactan } t} \Delta H_{f}^{0}$ are sums of the HOFs for products and reactants in gas at $298.15 \mathrm{~K}$, respectively. $\Delta(P V)$ equals $\Delta n R T$ for reaction in gas phase and $\Delta n=0$ for isodemic reactions.

Detonation velocity (D) and pressure (P) are the most important targets of scaling the detonation characteristics of energetic materials. Kamlet-Jacobs (K-J) equations $^{31,32}$ have been used to calculate $\mathrm{D}$ and $\mathrm{P}$ to quantitatively evaluate high energy density compound in molecular design. Detonation velocity (D) and pressure $(\mathrm{P})$ can be calculated using the following KamletJacobs (K-J) equations:

$$
\begin{gathered}
D=1.01 \times \Phi^{0.5}(1.0+1.3 \rho) \\
\Phi=N \bar{M}^{0.5} Q^{0.5} \\
P=1.558 \times \Phi \rho^{2}
\end{gathered}
$$

Where each term in eqs. (4) and (5) is defined as follows: P, detonation pressure (GPa); D, the detonation velocity $(\mathrm{km} / \mathrm{s}) ; \rho$, the packed density $\left(\mathrm{g} / \mathrm{cm}^{3}\right) ; \Phi$, the characteristics value of explosives; $\mathrm{N}$, the moles of gas produced by per gram of explosives; $\bar{M}$, an average molar weight of detonation products; and $Q$, the estimated heat of detonation (cal/g) defined as the difference between the heats of formation of the products and reactants of the most exothermic reactants. The density is obtained according to the method given by Politzer ${ }^{33}$ in which the electrostatic potential is considered. 
<smiles>[R]n1nnnc1N(C(F)(F)F)C(F)(F)C(F)(F)F</smiles>

$\mathrm{R}=\mathrm{CF}_{3}, \mathrm{CH}_{3}, \mathrm{CN}, \mathrm{H}, \mathrm{N}_{3}, \mathrm{NF}_{2}, \mathrm{NH}_{2}, \mathrm{NO}_{2}, \mathrm{ONO}_{2}$

A<smiles>[R]n1nnnc1N(C#N)N(C#N)c1nnnn1P</smiles>

$\mathrm{R}=\mathrm{CF}_{3}, \mathrm{CH}_{3}, \mathrm{CN}, \mathrm{H}, \mathrm{N}_{3}, \mathrm{NF}_{2}, \mathrm{NH}_{2}, \mathrm{NO}_{2}, \mathrm{ONO}_{2}$

C<smiles>[R]n1nnnc1N([NH])N([NH])c1nnnn1[R]</smiles>

$\mathrm{R}=\mathrm{CF}_{3}, \mathrm{CH}_{3}, \mathrm{CN}, \mathrm{H}, \mathrm{N}_{3}, \mathrm{NF}_{2}, \mathrm{NH}_{2}, \mathrm{NO}_{2}, \mathrm{ONO}_{2}$

E<smiles>[R]n1nnnc1N(N)N(N)c1nnnn1P</smiles>

$\mathrm{R}=\mathrm{CF}_{3}, \mathrm{CH}_{3}, \mathrm{CN}, \mathrm{H}, \mathrm{N}_{3}, \mathrm{NF}_{2}, \mathrm{NH}_{2}, \mathrm{NO}_{2}, \mathrm{ONO}_{2}$

$\mathrm{G}$<smiles>[R]n1nnnc1N([N+]([O-])O[N+]([R])=O)[N+](=O)[O-]</smiles>

$\mathrm{R}=\mathrm{CF}_{3}, \mathrm{CH}_{3}, \mathrm{CN}, \mathrm{H}, \mathrm{N}_{3}, \mathrm{NF}_{2}, \mathrm{NH}_{2}, \mathrm{NO}_{2}, \mathrm{ONO}_{2}$

I<smiles>[R]n1nnnc1N(C)N(C)c1nnnn1P</smiles>

$\mathrm{R}=\mathrm{CF}_{3}, \mathrm{CH}_{3}, \mathrm{CN}, \mathrm{H}, \mathrm{N}_{3}, \mathrm{NF}_{2}, \mathrm{NH}_{2}, \mathrm{NO}_{2}, \mathrm{ONO}_{2}$

$\mathrm{B}$<smiles>[R]n1nnnc1NNc1nnnn1P</smiles>

$\mathrm{R}=\mathrm{CF}_{3}, \mathrm{CH}_{3}, \mathrm{CN}, \mathrm{H}, \mathrm{N}_{3}, \mathrm{NF}_{2}, \mathrm{NH}_{3}, \mathrm{NO}_{2}, \mathrm{ONO}_{2}$

$\mathrm{D}$<smiles>[R]n1nnnc1N(N)N(c1nnnn1[R])[NH+](F)F</smiles>

$\mathrm{R}=\mathrm{CF}_{3}, \mathrm{CH}_{3}, \mathrm{CN}, \mathrm{H}, \mathrm{N}_{3}, \mathrm{NF}_{2}, \mathrm{NH}_{2}, \mathrm{NO}_{2}, \mathrm{ONO}_{2}$

$\mathrm{F}$<smiles>[R]n1nnnc1N(N(c1nnnn1[R])[N+](=O)[O-])[N+](=O)[O-]</smiles>

$\mathrm{R}=\mathrm{CF}_{3}, \mathrm{CH}_{3}, \mathrm{CN}, \mathrm{H}, \mathrm{N}_{3}, \mathrm{NF}_{2}, \mathrm{NH}_{2}, \mathrm{NO}_{2}, \mathrm{ONO}_{2}$

$\mathrm{H}$

Figure 1. Geometric structures and labelling of the compounds. 


\section{Results and Discussion}

\subsection{Heats of formation and densities}

These high-nitrogen fuels or explosives are noteworthy in that they represent a unique class of energetic materials that appear to contradict the performancesensitivity correlation. A significant amount of the chemical potential energy for these high-nitrogen compounds is derived from their high HOFs and not from oxidation of carbon in the backbone. Therefore, the $\mathrm{HOF}$ is frequently taken to be indicative of the 'energy content' of an energetic high-nitrogen compound. Here we investigated the effects of different substituents on the HOFs of the tetrazole-based energetic materials. Table 1 lists the total energies, ZPEs and thermal corrections at the B3LYP/6-311++G** level for 19 reference compounds in the isodesmic reactions. In these isodesmic reactions, the experimental HOFs of many reference compounds are available, while others HOF are not available. For example, the experimental HOF of furazan is not available. So additional calculations were carried out for the atomization reaction $\mathrm{CH}_{3} \mathrm{~N}_{3}(\mathrm{~g})=\mathrm{C}(\mathrm{g})+3 \mathrm{H}(\mathrm{g})+3 \mathrm{~N}(\mathrm{~g})$ to get an accurate value $\Delta H_{f}$ for $\mathrm{CH}_{3} \mathrm{~N}_{3}$. Similar calculations are made for $\mathrm{NH}_{2} \mathrm{~N}_{3}, \mathrm{NH}_{2} \mathrm{NF}_{2}, \mathrm{CH}_{3} \mathrm{NF}_{2}$ and $\mathrm{NH}_{2} \mathrm{ONO}_{2}$.

Table 2 summarizes the $\mathrm{E}_{0}, \mathrm{ZPE}$, density $\rho$ and $\mathrm{HOF}(\mathrm{g})$ for the bridged ditetrazoles. Previous researches $^{37-40}$ have shown that the predicted HOFs theoretically were in good agreement with the experimental HOFs when the appropriate isodesmic reaction was chosen. For A series, the substitution of $-\mathrm{N}_{3}$ or $-\mathrm{CN}$ group drastically increases the HOF values of the parent ditetrazoles $(\mathrm{A}-\mathrm{H})$, while the substitution of $-\mathrm{CF}_{3}$ drastically decreases the HOF value of the parent ditetrazoles (A-H). The same is true for the series B, C, D, E, F, G, H and I. From table 2, the HOFs of E series are all larger than the corresponding HOFs of the other series. In addition, it is noted that the HOF is the biggest for E- $\mathrm{N}_{3}$ which has four $-\mathrm{N}_{3}$ groups and the $\mathrm{HOF}$ is the smallest for $\mathrm{A}-\mathrm{CF}_{3}$ which has four $-\mathrm{CF}_{3}$ groups because of the difference of conjugate parameters. $-\mathrm{CF}_{3}$ group has larger and positive conjugate parameter, while $-\mathrm{N}_{3}$ group has negative conjugate parameter, which make them have drastically different effects on the HOF. This also suggests that the HOFs of the title compounds are drastically influenced by substituents.

Figure 2 presents a comparison of the HOF values for the different substituted groups. Generally, the influence of different substituted groups on $\mathrm{HOF}$ has the order of $-\mathrm{N}_{3}>-\mathrm{CN}>-\mathrm{NH}_{2}>-\mathrm{NO}_{2}>-\mathrm{NF}_{2}>-\mathrm{ONO}_{2}>-$ $\mathrm{H}>-\mathrm{CH}_{3}>-\mathrm{CF}_{3}$. This indicates that the azo group is an effective substituted group to increase the HOFs of the title compounds. The incorporation of $-\mathrm{CF}_{3}$ or $-\mathrm{CH}_{3}$ group is unfavorable for increasing HOF.

The Kamlet-Jacobs equations (4) and (5) show that density is a key factor to influence detonation velocity and detonation pressure. Thus, density is one of the most important physical properties of all energetic materials. Densities of the studied compounds are obtained according to Politzer et al..$^{33}$ The obtained densities of the title compounds are also lists in table 2. It is noted that the ditetrazole derivatives with different substituent groups have different densities, for example, the largest value and the smallest one is $2.29 \mathrm{~g} / \mathrm{cm}^{3}$ and $1.37 \mathrm{~g} / \mathrm{cm}^{3}$, respectively. This makes the ditetrazole

Table 1. Calculated total energies $\left(\mathrm{E}_{0}\right)$, zero-point energies (ZPE) and heats of formation $(\mathrm{HOFs})$ for the reference compounds. $E_{0}$ and ZPE are in a.u., $\mathrm{HOF}$ are in $\mathrm{kJ} / \mathrm{mol}$.

\begin{tabular}{lccccccc}
\hline Compds & $E_{0}$ & ZPE & HOF & \multicolumn{1}{c}{ Compds } & $E_{0}$ & ZPE & HOF \\
\hline $\mathrm{CH}_{4}$ & -40.48941 & 0.0446 & $-74.4^{a}$ & $\mathrm{CF}_{3} \mathrm{NH}_{2}$ & -393.6927 & 0.04102 & $-717.6^{e}$ \\
$\mathrm{C}_{2} \mathrm{H}_{6}$ & -79.7552 & 0.0752 & $-84.68^{a}$ & $\mathrm{NH}_{2} \mathrm{CN}$ & -148.8010 & 0.03397 & $154.67^{a}$ \\
$\mathrm{CH}_{3} \mathrm{CF}_{3}$ & -377.6346 & 0.0519 & $-748.7^{b}$ & $\mathrm{NH}_{3}$ & -56.5485 & 0.0343 & $-45.9^{a}$ \\
$\mathrm{CH}_{3} \mathrm{CN}$ & -132.7511 & 0.0452 & $75.32^{a}$ & $\mathrm{NH}_{2} \mathrm{~N}_{3}$ & -220.1283 & 0.03878 & $435.1^{d}$ \\
$\mathrm{CH}_{3} \mathrm{NH}_{2}$ & -95.7888 & 0.0644 & $-23.01^{a}$ & $\mathrm{NH}_{2} \mathrm{NF}_{2}$ & -310.2959 & 0.0349 & $-20.0^{d}$ \\
$\mathrm{CH}_{3} \mathrm{NO}_{2}$ & -244.9592 & 0.05018 & $-80.8^{a}$ & $\mathrm{NH}_{2} \mathrm{NH}_{2}$ & -111.8531 & 0.0525 & $95.35^{b}$ \\
$\mathrm{CH}_{3} \mathrm{~N}_{3}$ & -204.0695 & 0.0496 & $296.54^{d}$ & $\mathrm{NH}_{2} \mathrm{NO}_{2}$ & -261.0691 & 0.0382 & $-3.9^{a}$ \\
$\mathrm{CH}_{3} \mathrm{NF}_{2}$ & -294.2638 & 0.0466 & $-115.2^{d}$ & $\mathrm{NH}_{2} \mathrm{ONO}_{2}$ & -336.2416 & 0.0419 & $27.2^{d}$ \\
$\mathrm{CH}_{3} \mathrm{ONO}_{2}$ & -320.2390 & 0.0540 & $-124.4^{a}$ & $\mathrm{CH}_{3} \mathrm{NHNHCH}_{3}$ & -190.4372 & 0.1090 & $92.2^{a}$ \\
$1 \mathrm{H}$-tetrazole & -258.2776 & 0.0466 & $333.2^{c}$ & & & & \\
\hline
\end{tabular}

${ }^{a}$ The HOF data are taken from Refs. ${ }^{34}$
${ }^{b}$ The HOF data are taken from Refs. ${ }^{35}$
${ }^{c}$ The HOF data are taken from Refs. ${ }^{36}$
${ }^{d}$ The values are calculated at $\mathrm{G} 2$ level
${ }^{e}$ The values are calculated from the isodesmic reaction: $\mathrm{CF}_{3} \mathrm{NH}_{2}+\mathrm{CH}_{4} \rightarrow \mathrm{CH}_{3} \mathrm{CF}_{3}+\mathrm{NH}_{3}$ 
Table 2. Calculated total energies $\left(\mathrm{E}_{0}\right)$, zero-point energies (ZPE), and heats of formation (HOFs) for the ditetrazole derivatives, $E_{0}$ and $\mathrm{ZPE}$ are in a.u., $\rho$ is in $\mathrm{g} / \mathrm{cm}^{3}, \mathrm{HOF}$ is in $\mathrm{kJ} / \mathrm{mol}$.

\begin{tabular}{|c|c|c|c|c|c|c|c|c|c|}
\hline Compd. & $E_{0}$ & $\mathrm{ZPE}$ & $\mathrm{HOF}$ & $\rho$ & Compd. & $E_{0}$ & ZPE & $\mathrm{HOF}$ & $\rho$ \\
\hline CF3 & 1974.535914 & 122775 & -1794.9 & 2.29 & $\mathrm{~B}-\mathrm{CF} 3$ & -1378.873080 & 0.170660 & -627.8 & 1 \\
\hline & & & -675.0 & 1.88 & $\mathrm{~B}-\mathrm{CH} 3$ & -783.210910 & 218743 & 379.0 & 1.37 \\
\hline $\mathrm{CN}$ & 1484.752030 & 110235 & 109.4 & 1.92 & $\mathrm{~B}-\mathrm{CN}$ & -889.096319 & .157873 & 1099.3 & 1.53 \\
\hline & 1300.307882 & & -451.5 & 2.05 & B-H & -704.628969 & 162636 & 599.3 & 1.47 \\
\hline N3 & 1627.448673 & .118249 & 421.8 & 1.87 & B-N3 & -1031.779760 & 0.165707 & 1584.4 & 1.58 \\
\hline NF2 & 1807.757352 & 110682 & -280.7 & 2.01 & B-NF2 & -1212.099456 & 0.158003 & 714.9 & 1.75 \\
\hline -NH2 & 1410.942160 & .148709 & -234.8 & 2.01 & B-NH2 & -815.271237 & 0.196709 & 795.0 & 1.49 \\
\hline & 1709.298118 & 7019 & -233.7 & 2.13 & $\mathrm{~B}-\mathrm{N}$ & -1113.638830 & 0.164913 & 765.6 & 1.71 \\
\hline $\mathrm{A}-\mathrm{ONO} 2$ & 1859.685762 & .118963 & -421.6 & 2.03 & $\mathrm{~B}-\mathrm{ONO}$ & -1264.024916 & 0.171823 & 719.9 & 1.69 \\
\hline rid & -1484.746160 & 11( & 124.8 & 1.98 & $\mathrm{D}$ & -1300 & & -427.7 & 2.03 \\
\hline & -889.108831 & 158880 & 106 & 1.55 & & -704.639238 & & 572.3 & 1.45 \\
\hline & -994.9 & 09 & 187 & 1.67 & 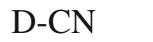 & -810 & 1 & 1755.2 & 1.68 \\
\hline & & 97 & 131 & 1. & & & & & 1.58 \\
\hline & -11 & 1 & 2183.7 & 1.66 & & -9 & .094268 & 1947.1 & 1.68 \\
\hline & 7.96 & 09 & 148 & 1. & & -1133. & & 932.5 & 1.91 \\
\hline & -921.159245 & 12 & 150 & 1.5 & & -736 & & 1000.0 & 1.57 \\
\hline & -12 & & & 1. & & & & & 1.82 \\
\hline & $-13 \mathrm{c}$ & 11 & 146 & 1.78 & & & & 935.4 & 1.80 \\
\hline & & & & 2. & & & & & 2.22 \\
\hline & -10 & 8 & 15 & 1. & & & & & 1.79 \\
\hline & & & & & & & & & 1.88 \\
\hline $\mathrm{E}$ & 7746 & 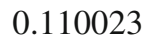 & 177 & 1. & & -1 & & & 1.92 \\
\hline & 6 & & & & & & & & 1.93 \\
\hline & -14 & 4 & 19 & 1. & & -1 & & 911.2 & 2.14 \\
\hline & & & & & & & & & 1.91 \\
\hline & -13 & 4 & 195 & 1. & & & & 88 & 2.00 \\
\hline & & & & & & & & & 2.04 \\
\hline & -14 & & -38 & 1 . & & & & -4 & 2.12 \\
\hline & & & & & & & & & 1.69 \\
\hline & -92 & & 13 & & & & & 12 & 1.80 \\
\hline $\mathrm{G}$ & & & & & & & & & 1.8 \\
\hline G-I & -10 & & 184 & & & & & 18 & 1.99 \\
\hline & & & & & & & & & 2.02 \\
\hline & -84 & & & & & -1 & & 926.7 & 176 \\
\hline G-N & -11 & 0 & 101 & & & & & & 1.93 \\
\hline & -12 & & & & & & & 878.5 & 1.94 \\
\hline I-C & 6 & 0.12 & -445 & 2. & & & & & 2.01 \\
\hline $\mathrm{I}-\mathrm{C}$ & & & & & & & & & \\
\hline $\mathrm{I}-\mathrm{C}$ & .913438 & 0.11 & 1293.9 & 1.80 & $\mathrm{I}-\mathrm{NO}$ & -1 & & 942.3 & 1.98 \\
\hline I-H & & & 75 & 1.80 & I-ONO2 & -1744.846138 & 0.125693 & 903.8 & 1.93 \\
\hline $\mathrm{I}-\mathrm{N}$ & 1512.586242 & 0.117625 & 1807.0 & 1.82 & & & & & \\
\hline
\end{tabular}

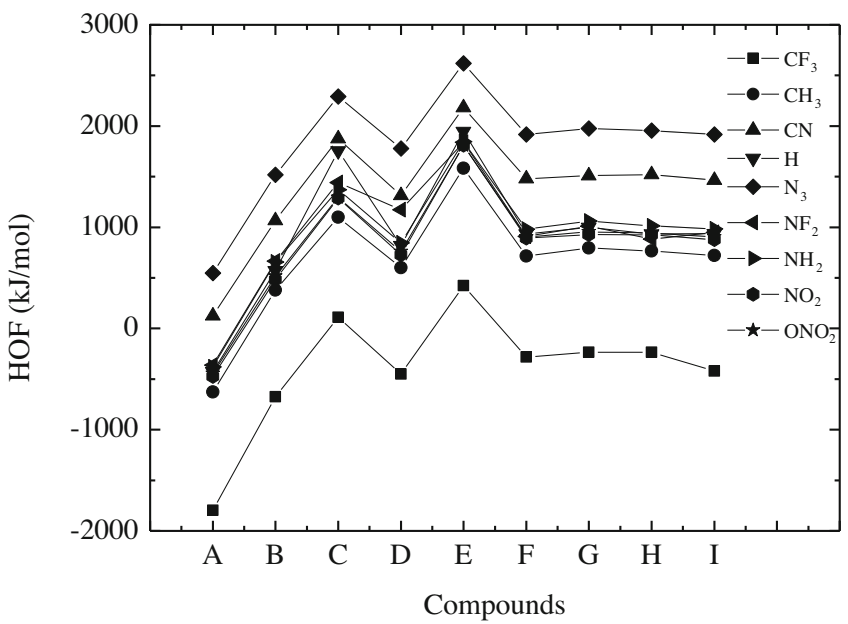

Figure 2. Influence of various substituted groups on heats of formation.

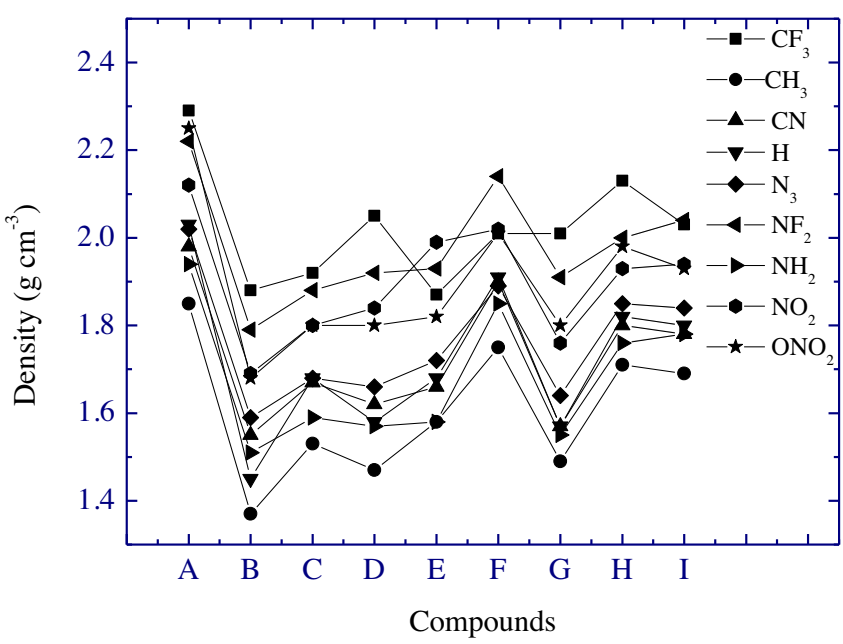

Figure 3. Influence of various substituted groups on densities. 
derivatives have different detonation velocity and pressure.

Figure 3 presents a comparison of the densities of all compounds. It can be seen that the densities of the compounds with $-\mathrm{CF}_{3}$ groups ranges from 1.88 to $2.29 \mathrm{~g} / \mathrm{cm}^{3}$ and the densities of the compounds with $\mathrm{CH}_{3}$ groups ranges from 1.37 to $1.85 \mathrm{~g} / \mathrm{cm}^{3}$. The compound $\mathrm{A}-\mathrm{CF}_{3}$ with four $-\mathrm{CF}_{3}$ groups has the largest density and the compound $\mathrm{B}-\mathrm{CH}_{3}$ with four $-\mathrm{CH}_{3}$ groups has the smallest density. This indicates that the introduction of $-\mathrm{CF}_{3}$ groups is more favourable for increasing the density and the introduction of $-\mathrm{CH}_{3}$ groups is not favourable for increasing the density. In addition, it is noted that the densities of the compounds with $-\mathrm{NF}_{2}$ group such as A-NF $2, \mathrm{C}-\mathrm{NF}_{2}, \mathrm{D}-\mathrm{NF}_{2}, \mathrm{E}-\mathrm{NF}_{2}$, $\mathrm{F}-\mathrm{NF}_{2}$ range from 1.75 to $2.14 \mathrm{~g} / \mathrm{cm}^{3}$.

Table 3. Predicted heat of detonation (Q), detonation velocities (D), detonation pressures $(\mathrm{P})$ and oxygen balance $\left(\mathrm{OB}_{100}\right)$ for the title compounds.

\begin{tabular}{|c|c|c|c|c|c|c|c|c|c|}
\hline Compd. & $\mathrm{Q}(\mathrm{kJ} / \mathrm{g})$ & $\mathrm{D}(\mathrm{km} / \mathrm{s})$ & $\mathrm{P}(\mathrm{GPa})$ & $\mathrm{OB}_{100}$ & Compd. & $\mathrm{Q}(\mathrm{kJ} / \mathrm{g})$ & $\mathrm{D}(\mathrm{km} / \mathrm{s})$ & $\mathrm{P}(\mathrm{GPa})$ & $\mathrm{OB}_{100}$ \\
\hline $\mathrm{A}-\mathrm{CF} 3$ & 647.7 & 8.38 & 35.5 & - & B-CF3 & 720.7 & 7.15 & 23.1 & - \\
\hline $\mathrm{A}-\mathrm{CH} 3$ & 686.7 & 7.15 & 23.2 & - & $\mathrm{B}-\mathrm{CH} 3$ & 693.0 & 5.31 & 10.5 & -0.080 \\
\hline $\mathrm{A}-\mathrm{CN}$ & 1082.3 & 8.06 & 30.0 & - & $\mathrm{B}-\mathrm{CN}$ & 1199.4 & 6.62 & 17.6 & -0.061 \\
\hline A-H & 854.8 & 8.26 & 32.6 & - & B-H & 950.7 & 6.33 & 15.6 & -0.061 \\
\hline A-N3 & 1186.0 & 8.45 & 32.4 & - & B-N3 & 1478.4 & 7.68 & 24.1 & -0.040 \\
\hline A-NF2 & 1300.3 & 9.25 & 40.5 & - & B-NF2 & 1480.5 & 8.46 & 31.2 & - \\
\hline A-NH2 & 965.4 & 8.47 & 33.9 & - & B-NH2 & 1079.1 & 6.74 & 17.8 & -0.058 \\
\hline A-NO2 & 1241.7 & 9.50 & 44.0 & - & $\mathrm{B}-\mathrm{NO} 2$ & 1410.5 & 8.19 & 28.8 & -0.024 \\
\hline $\mathrm{A}-\mathrm{ONO} 2$ & 1263.8 & 9.28 & 40.9 & - & $\mathrm{B}-\mathrm{ONO} 2$ & 1530.0 & 8.40 & 30.1 & -0.018 \\
\hline C-CF3 & 1092.7 & 8.26 & 32.0 & - & D-CF3 & 873.5 & 8.25 & 32.3 & - \\
\hline $\mathrm{C}-\mathrm{CH} 3$ & 1167.5 & 6.64 & 17.8 & -0.061 & D-CH3 & 917.8 & 6.22 & 14.9 & -0.061 \\
\hline $\mathrm{C}-\mathrm{CN}$ & 1671.7 & 7.61 & 24.6 & -0.045 & D-CN & 1973.7 & 8.30 & 29.3 & -0.041 \\
\hline C-H & 1490.2 & 7.54 & 23.6 & -0.041 & D-H & 1292.4 & 7.57 & 23.4 & -0.036 \\
\hline C-N3 & 1739.7 & 8.21 & 28.4 & -0.027 & D-N3 & 1904.5 & 8.84 & 33.2 & -0.02 \\
\hline C-NF2 & 1849.6 & 9.38 & 40.3 & - & D-NF2 & 1746.8 & 9.68 & 43.0 & - \\
\hline C-NH2 & 1540.6 & 7.61 & 23.6 & -0.040 & D-NH2 & 1370.3 & 7.77 & 24.6 & -0.035 \\
\hline C-NO2 & 1791.5 & 8.89 & 35.1 & -0.013 & D-NO2 & 1635.1 & 9.16 & 37.4 & -0.004 \\
\hline $\mathrm{C}-\mathrm{ONO} 2$ & 1859.4 & 9.02 & 35.9 & -0.006 & $\mathrm{D}-\mathrm{ONO} 2$ & 1618.3 & 9.10 & 36.8 & 0.003 \\
\hline E-CF3 & 1264.2 & 9.08 & 39.1 & - & F-CF3 & 1252.2 & 9.86 & 48.4 & - \\
\hline E-CH3 & 1421.8 & 7.64 & 24.0 & -0.040 & $\mathrm{~F}-\mathrm{CH} 3$ & 1441.7 & 8.53 & 32.2 & - \\
\hline $\mathrm{E}-\mathrm{CN}$ & 1826.6 & 8.38 & 29.8 & -0.027 & $\mathrm{~F}-\mathrm{CN}$ & 1819.8 & 9.27 & 39.1 & - \\
\hline E-H & 1743.4 & 8.57 & 31.0 & -0.020 & F-H & 1960.5 & 10.0 & 46.1 & - \\
\hline E-N3 & 1885.7 & 9.02 & 35.1 & -0.012 & F-N3 & 1924.8 & 10.0 & 46.2 & - \\
\hline E-NF2 & 1977.1 & 9.92 & 44.9 & - & F-NF2 & 1865.0 & 10.9 & 57.6 & - \\
\hline E-NH2 & 1763.6 & 8.61 & 31.0 & -0.021 & F-NH2 & 1670.5 & 9.64 & 42.7 & - \\
\hline E-NO2 & 1927.3 & 9.67 & 42.1 & 0 & F-NO2 & 1509 & 9.26 & 40.4 & - \\
\hline E-ONO2 & 1737.4 & 9.37 & 39.5 & 0.005 & F-ONO2 & 1423.7 & 9.67 & 44.6 & 0.005 \\
\hline G-CF3 & 861.3 & 8.03 & 29.9 & - & $\mathrm{H}-\mathrm{CF} 3$ & 1095.3 & 9.18 & 41.0 & - \\
\hline G-CH3 & 933.1 & 6.55 & 17.0 & -0.058 & $\mathrm{H}-\mathrm{CH} 3$ & 1173.9 & 7.75 & 25.7 & -0.024 \\
\hline G-CN & 1407.5 & 7.50 & 23.1 & -0.040 & $\mathrm{H}-\mathrm{CN}$ & 1611.0 & 8.66 & 33.3 & -0.013 \\
\hline G-H & 1182.8 & 7.49 & 22.8 & -0.035 & $\mathrm{H}-\mathrm{H}$ & 1443.3 & 8.94 & 35.9 & -0.004 \\
\hline G-N3 & 1653.1 & 8.26 & 27.9 & -0.021 & H-N3 & 1826.1 & 10.0 & 47.4 & 0 \\
\hline G-NF2 & 1647.7 & 9.39 & 39.8 & - & H-NF2 & 1513.2 & 9.33 & 41.3 & - \\
\hline G-NH2 & 1301.5 & 7.68 & 23.8 & -0.035 & H-NH2 & 1497.0 & 8.82 & 34.1 & -0.007 \\
\hline G-NO2 & 1568.1 & 8.93 & 34.9 & -0.007 & $\mathrm{H}-\mathrm{NO} 2$ & 1174.8 & 8.75 & 35.4 & 0.012 \\
\hline G-ONO2 & 1681.5 & 9.23 & 37.5 & 0 & $\mathrm{H}-\mathrm{ONO} 2$ & 1047.5 & 8.53 & 33.7 & 0.016 \\
\hline I-CF3 & 1250.2 & 9.98 & 50.0 & - & I-NF2 & 1398.3 & 9.49 & 42.4 & - \\
\hline I-CH3 & 1377.9 & 8.15 & 28.2 & -0.016 & I-NH2 & 1661.6 & 9.27 & 38.2 & 0 \\
\hline I-CN & 1739.4 & 8.94 & 35.5 & -0.006 & I-NO2 & 1087.7 & 8.74 & 35.8 & 0.016 \\
\hline $\mathrm{I}-\mathrm{H}$ & 1474.0 & 8.89 & 35.1 & 0.003 & I-ONO2 & 980.8 & 8.36 & 32.3 & 0.019 \\
\hline I-N3 & 1666.6 & 9.21 & 37.8 & 0.005 & $\mathrm{HMX}^{b}$ & 6.76 & $9.35(9.1)$ & $38.2(39.0)$ & -0.22 \\
\hline $\mathrm{RDX}^{b}$ & 6.50 & $8.98(8.75)$ & $35.1(34.0)$ & -0.22 & & & & & \\
\hline
\end{tabular}

${ }^{a}$ For the explosive $\mathrm{C}_{a} \mathrm{H}_{b} \mathrm{O}_{c} \mathrm{~N}_{d}$ : $\mathrm{OB}=(\mathrm{c}-2 \mathrm{a}-0.5 \mathrm{~b}) / \mathrm{M}_{w}$, where $\mathrm{M}_{w}$ is the molecular weight

${ }^{b}$ Data in parentheses are the experimental values taken from ref. ${ }^{42,43}$ 


\subsection{Detonation performance}

Based on the HOFs and the densities, detonation velocity and detonation are evaluated for these title compounds. Table 3 presents the calculated $Q, D, P$ and oxygen balance $(\mathrm{OB})$ for these title compounds. For comparison, the experimental detonation performances of HMX and RDX are also listed in table 3. The HOFs of HMX and RDX are obtained through the isodesmic reaction: $\mathrm{X}-\left(\mathrm{NO}_{2}\right)_{\mathrm{n}}+\mathrm{nCH}_{4} \rightarrow \mathrm{X}-\mathrm{H}+\mathrm{nCH}_{3} \mathrm{NO}_{2}$ $(4 \leq \mathrm{n} \leq 8)$, where the HOF of $\mathrm{X}-\mathrm{H}$ molecule is carried out for the atomization reaction by G2 theory. For HMX and RDX, the calculated detonation velocities and pressures agree well with the available experimental data. ${ }^{41,42}$ This shows that our predictions for the title compounds are reliable and further confirm the reliability of the used calculational method. Figures 4 and 5 present the comparison of detonation velocity and pressure for the different substituted groups.

The calculated heats of detonation $(Q)$ in table 3 show that introducing $-\mathrm{CN},-\mathrm{N}_{3}$ or $-\mathrm{NF}_{2}$ group always increases the $Q$. Oxygen balance is one of the most important parameters of energetic materials. Generally, the higher the oxygen balance is, the larger the $\mathrm{D}$ and $\mathrm{P}$ values are. The $-\mathrm{NO}_{2}$ or $-\mathrm{ONO}_{2}$ group is a good substituent to improve oxygen balance. In addition, it is noted that too much oxygen is not favourable for advancing explosive performance of energetic materials, because the additional oxygen will produce additional $\mathrm{O}_{2}$ that take away a great deal of energy during the explosion of high energy materials. Therefore, one should keep the value of oxygen balance around zero in designing HEDMs.

It is noted from table 3 that the densities of $\mathrm{A}\left(-\mathrm{NF}_{2}\right.$, $\left.\mathrm{NO}_{2},-\mathrm{ONO}_{2}\right), \mathrm{C}-\mathrm{NF}_{2}, \mathrm{D}-\mathrm{NF}_{2}, \mathrm{E}\left(-\mathrm{CF}_{3},-\mathrm{NF}_{2}\right), \mathrm{F}\left(-\mathrm{CF}_{3}\right.$,

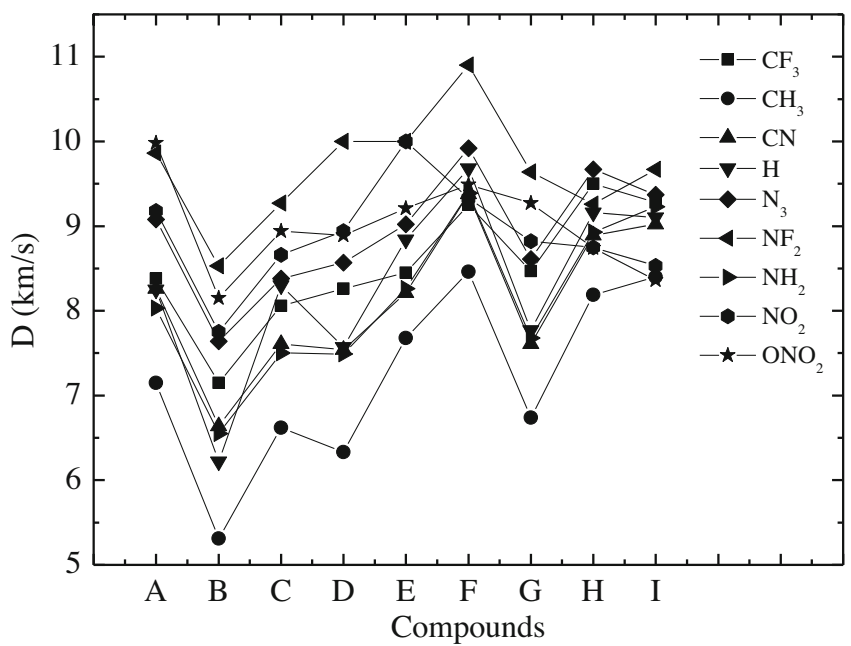

Figure 4. Influence of various substituted groups on detonation velocity.
$\left.-\mathrm{CN},-\mathrm{H},-\mathrm{N}_{3},-\mathrm{NF}_{2},-\mathrm{NH}_{2},-\mathrm{NO}_{2},-\mathrm{ONO}_{2}\right), \mathrm{G}-\mathrm{NF}_{2}, \mathrm{H}$ $\left(-\mathrm{CF}_{3},-\mathrm{N}_{3},-\mathrm{NF}_{2}\right)$ and $\mathrm{I}_{-} \mathrm{NF}_{2}$ are very high and close to or above $1.9 \mathrm{~g} / \mathrm{cm}^{3}$. Their $\mathrm{D}$ and $\mathrm{P}$ are all very high and close to or above $9.0 \mathrm{~km} / \mathrm{s}$ and $40.0 \mathrm{GPa}$, respectively. Obviously, all the series combined with $-\mathrm{NF}_{2}$ group except $\mathrm{B}-\mathrm{NF}_{2}$ have higher densities, $\mathrm{D}$ and $\mathrm{P}$. It is noted that $\mathrm{F}-\mathrm{NF}_{2}$ has the largest detonation velocity and pressure among these derivatives. This shows that $-\mathrm{NF}_{2}$ group is an effective structural unit to increase the detonation performance of the studied compounds. For other series, similar analysis can be made. This indicates that different substituents have different effects on $\mathrm{D}$ and $\mathrm{P}$.

$\mathrm{A}-\mathrm{CH}_{3}$ and $\mathrm{B}-\mathrm{CF}_{3}$ are isomers with the different position of substituted groups. It is noted that $\mathrm{D}$ and $\mathrm{P}$ for $\mathrm{A}-\mathrm{CH}_{3}$ are $7.15 \mathrm{~km} / \mathrm{s}$ and $23.2 \mathrm{GPa}$, respectively, $7.15 \mathrm{~km} / \mathrm{s}$ and $23.1 \mathrm{GPa}$ for $\mathrm{B}-\mathrm{CF}_{3}$, respectively. $\mathrm{E}-\mathrm{NF}_{2}$ and $\mathrm{F}-\mathrm{N}_{3}$ are also isomers with the different position of substituted groups. D and $\mathrm{P}$ for $\mathrm{E}-\mathrm{NF}_{2}$ are $9.92 \mathrm{~km} / \mathrm{s}$ and $44.9 \mathrm{GPa}$, respectively. D and $\mathrm{P}$ for $\mathrm{F}-\mathrm{N}_{3}$ are $10.00 \mathrm{~km} / \mathrm{s}$ and $46.2 \mathrm{GPa}$, respectively. Obviously, the differences between $\mathrm{D}$ and $\mathrm{P}$ for $\mathrm{A}-\mathrm{CH}_{3}$ and $\mathrm{B}-\mathrm{CF}_{3}, \mathrm{E}-\mathrm{NF}_{2}$ and $\mathrm{F}-\mathrm{N}_{3}$ are very small. A similar analysis can be made for other isomers. This shows that the position of substituted groups has little effect on D and P for isomers.

\subsection{Electronic properties}

The most important orbitals in a molecule are the frontier molecular orbitals, called highest occupied molecular orbital (HOMO) and lowest unoccupied molecular orbital (LUMO). These orbitals determine the way the molecule interacts with other species. The frontier orbital gap helps characterize the chemical reactivity

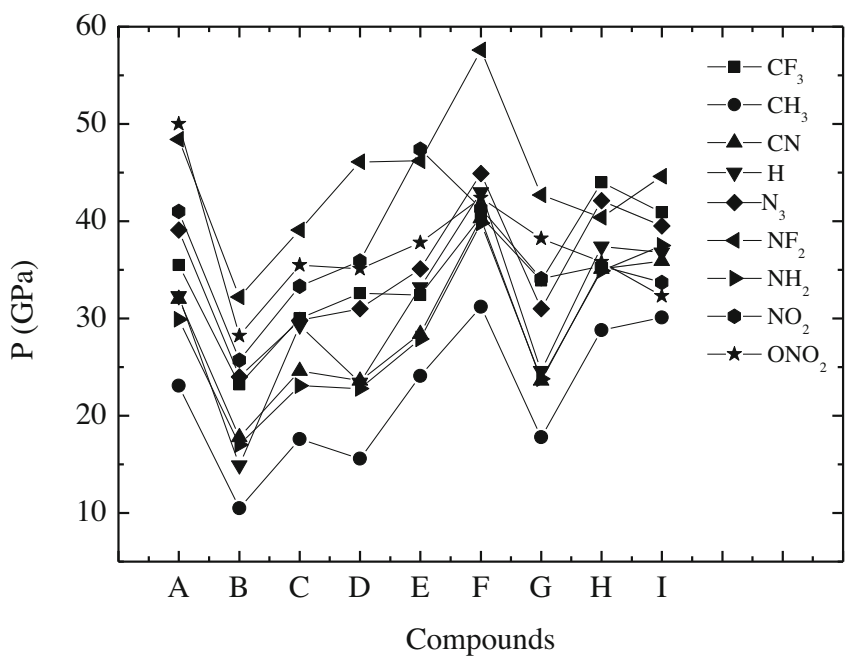

Figure 5. Influence of various substituted groups on detonation pressure. 
and kinetic stability of the molecule. A molecule with a small frontier orbital gap is more polarizable and is generally associated with a high chemical reactivity, low kinetic stability and is also termed as soft molecule. ${ }^{43}$ Table 4 lists the highest occupied molecular orbital energies $\left(\mathrm{E}_{\mathrm{HOMO}}\right)$, the lowest unoccupied molecular orbital energies $\left(\mathrm{E}_{\mathrm{LUMO}}\right)$ and the energy gaps $\left(\Delta \mathrm{E}_{\mathrm{LUMO}-\mathrm{HOMO}}\right)$ for the title compounds. For $\mathrm{A}$ series, we can consider the A-H compound as the parent compound and investigate the substituent groups on the $\mathrm{E}_{\mathrm{HOMO}}, \mathrm{E}_{\mathrm{LumO}}$ and $\Delta \mathrm{E}_{\mathrm{LumO}-\mathrm{HOMO}}$. From table 4 , when the $\mathrm{H}$ atom of $\mathrm{A}-\mathrm{H}$ compound is substituted by
$-\mathrm{NH}_{2}$ or $-\mathrm{CH}_{3}$ group, $\mathrm{E}_{\text {Hомо }}$ increases, whereas the substituent of other group such as $-\mathrm{CN},-\mathrm{CF}_{3},-\mathrm{N}_{3}$, $-\mathrm{NF}_{2},-\mathrm{NO}_{2}$ or $-\mathrm{ONO}_{2}$ will make $\mathrm{E}_{\mathrm{HOMO}}$ decrease. Similarly, the substituent $-\mathrm{CN},-\mathrm{CF}_{3},-\mathrm{N}_{3},-\mathrm{NF}_{2},-\mathrm{NO}_{2}$ or $-\mathrm{ONO}_{2}$ decreases $\mathrm{E}_{\mathrm{LUMO}}$ as compared to A-H compound, whereas $-\mathrm{NH}_{2}$ or $-\mathrm{CH}_{3}$ group increases $\mathrm{E}_{\mathrm{LUMO}}$. This indicates that different substituents have different effects on $\mathrm{E}_{\text {Hомо }}$ and $\mathrm{E}_{\mathrm{LUMO}}$. A similar analysis can be made for series B, C, D, E, F, G, H and I.

In addition, for A-H, B-H, C-H, D-H, E-H, F-H, G-H, $\mathrm{H}-\mathrm{H}$ and $\mathrm{I}-\mathrm{H}$ compounds, we can consider $\mathrm{D}-\mathrm{H}$ as parent compound and other compounds as the substituted

Table 4. Calculated $\mathrm{E}_{\mathrm{HOMO}}(\mathrm{a} . \mathrm{u}), \mathrm{E}_{\mathrm{LumO}}(\mathrm{a} . \mathrm{u})$ and $\Delta \mathrm{E}_{\mathrm{LUMO}-\mathrm{HOMO}}(\mathrm{a} . \mathrm{u})$ of the title compounds at B3LYP/6-311++G** level.

\begin{tabular}{|c|c|c|c|c|c|c|c|}
\hline Compd. & $\mathrm{E}_{\text {НОмо }}$ & $\mathrm{E}_{\mathrm{LUMO}}$ & $\Delta \mathrm{E}_{\text {LUMO-HOMO }}$ & Compd. & $\mathrm{E}_{\text {НОмо }}$ & $\mathrm{E}_{\text {LUMO }}$ & $\Delta \mathrm{E}_{\text {LUMO-номо }}$ \\
\hline $\mathrm{A}-\mathrm{CF} 3$ & -0.33864 & -0.10941 & 0.22923 & $\mathrm{~B}-\mathrm{CF} 3$ & -0.28161 & -0.06753 & 0.21408 \\
\hline $\mathrm{A}-\mathrm{CH} 3$ & -0.30578 & -0.06857 & 0.23721 & $\mathrm{~B}-\mathrm{CH} 3$ & -0.25322 & -0.04099 & 0.21223 \\
\hline $\mathrm{A}-\mathrm{CN}$ & -0.33962 & -0.12046 & 0.21916 & $\mathrm{~B}-\mathrm{CN}$ & -0.30031 & -0.09135 & 0.20896 \\
\hline A-H & -0.31324 & -0.07390 & 0.23934 & B-H & -0.26251 & -0.04816 & 0.21435 \\
\hline A-N3 & -0.31524 & -0.12292 & 0.19232 & $\mathrm{~B}-\mathrm{N} 3$ & -0.26875 & -0.11113 & 0.15762 \\
\hline A-NF2 & -0.33821 & -0.11021 & 0.22800 & $\mathrm{~B}-\mathrm{NF} 2$ & -0.29503 & -0.08752 & 0.20751 \\
\hline $\mathrm{A}-\mathrm{NH} 2$ & -0.30461 & -0.06597 & 0.23864 & $\mathrm{~B}-\mathrm{NH} 2$ & -0.25277 & -0.03876 & 0.21401 \\
\hline $\mathrm{A}-\mathrm{NO} 2$ & -0.33531 & -0.15643 & 0.17888 & $\mathrm{~B}-\mathrm{NO} 2$ & -0.29071 & -0.14098 & 0.14973 \\
\hline $\mathrm{A}-\mathrm{ONO} 2$ & -0.32303 & -0.13953 & 0.1835 & B-ONO2 & -0.28068 & -0.12887 & 0.15181 \\
\hline C-CF3 & -0.33267 & -0.10460 & 0.22807 & D-CF3 & -0.30455 & -0.07705 & 0.2275 \\
\hline $\mathrm{C}-\mathrm{CH} 3$ & -0.31135 & -0.08353 & 0.22782 & $\mathrm{D}-\mathrm{CH} 3$ & -0.27109 & -0.03585 & 0.23524 \\
\hline $\mathrm{C}-\mathrm{CN}$ & -0.34837 & -0.12754 & 0.22083 & $\mathrm{D}-\mathrm{CN}$ & -0.28515 & -0.13103 & 0.15412 \\
\hline $\mathrm{C}-\mathrm{H}$ & -0.32527 & -0.10027 & 0.22500 & $\mathrm{D}-\mathrm{H}$ & -0.28082 & -0.05651 & 0.22431 \\
\hline $\mathrm{C}-\mathrm{N} 3$ & -0.33215 & 0.12289 & 0.20926 & D-N3 & -0.29857 & -0.11257 & 0.18600 \\
\hline C-NF2 & -0.34238 & -0.12345 & 0.21893 & D-NF2 & -0.31431 & -0.10027 & 0.21404 \\
\hline C-NH2 & -0.30679 & -0.08368 & 0.22311 & D-NH2 & -0.26706 & -0.04316 & 0.2239 \\
\hline $\mathrm{C}-\mathrm{NO} 2$ & -0.33684 & -0.16596 & 0.17088 & D-NO2 & -0.31335 & -0.14642 & 0.16693 \\
\hline C-ONO2 & -0.32950 & -0.15096 & 0.17854 & $\mathrm{D}-\mathrm{ONO} 2$ & -0.30433 & -0.13430 & 0.17003 \\
\hline E-CF3 & -0.30542 & -0.12079 & 0.18463 & $\mathrm{~F}-\mathrm{CF} 3$ & -0.34516 & -0.11302 & 0.23214 \\
\hline E-CH3 & -0.28775 & -0.09654 & 0.19121 & F-CH3 & -0.31286 & -0.07978 & 0.23308 \\
\hline $\mathrm{E}-\mathrm{CN}$ & -0.31775 & -0.13193 & 0.18582 & $\mathrm{~F}-\mathrm{CN}$ & -0.35401 & -0.12332 & 0.23069 \\
\hline E-H & -0.28349 & -0.12207 & 0.16142 & $\mathrm{~F}-\mathrm{H}$ & -0.32102 & -0.07914 & 0.24188 \\
\hline E-N3 & -0.29984 & -0.13458 & 0.16526 & F-N3 & -0.33249 & -0.13476 & 0.19773 \\
\hline E-NF2 & -0.30919 & -0.12670 & 0.18249 & F-NF2 & -0.34802 & -0.12093 & 0.22709 \\
\hline E-NH2 & -0.27722 & -0.10327 & 0.17395 & $\mathrm{~F}-\mathrm{NH} 2$ & -0.31195 & -0.05964 & 0.25231 \\
\hline E-NO2 & -0.30809 & -0.15351 & 0.15458 & F-NO2 & -0.34127 & -0.12674 & 0.21453 \\
\hline E-ONO2 & -0.30023 & -0.14036 & 0.15987 & F-ONO2 & -0.34008 & -0.11982 & 0.22026 \\
\hline G-CF3 & -0.29183 & -0.06743 & 0.2244 & $\mathrm{H}-\mathrm{CF} 3$ & -0.33866 & -0.13471 & 0.20395 \\
\hline G-CH3 & -0.26475 & -0.03584 & 0.22891 & $\mathrm{H}-\mathrm{CH} 3$ & -0.31340 & -0.12070 & 0.1927 \\
\hline $\mathrm{G}-\mathrm{CN}$ & -0.31003 & -0.09418 & 0.21585 & $\mathrm{H}-\mathrm{CN}$ & -0.35013 & -0.14826 & 0.20187 \\
\hline G-H & -0.27837 & -0.04515 & 0.23322 & $\mathrm{H}-\mathrm{H}$ & -0.32449 & -0.13987 & 0.18462 \\
\hline G-N3 & -0.28526 & -0.10966 & 0.1756 & $\mathrm{H}-\mathrm{N} 3$ & -0.33524 & -0.15248 & 0.18276 \\
\hline G-NF2 & -0.30025 & -0.09270 & 0.20755 & H-NF2 & -0.34440 & -0.14206 & 0.20234 \\
\hline G-NH2 & -0.26981 & -0.04543 & 0.22438 & $\mathrm{H}-\mathrm{NH} 2$ & -0.30362 & -0.12623 & 0.17739 \\
\hline G-NO2 & -0.30168 & -0.14158 & 0.1601 & $\mathrm{H}-\mathrm{NO} 2$ & -0.34679 & -0.16660 & 0.18019 \\
\hline G-ONO2 & -0.31928 & -0.13587 & 0.18341 & $\mathrm{H}-\mathrm{ONO} 2$ & -0.32960 & -0.14673 & 0.18287 \\
\hline $\mathrm{I}-\mathrm{CF} 3$ & -0.31329 & -0.13405 & 0.17924 & I-NF2 & -0.31948 & -0.13830 & 0.18118 \\
\hline I-CH3 & -0.29085 & -0.12808 & 0.16277 & I-NH2 & -0.28976 & -0.12051 & 0.16925 \\
\hline $\mathrm{I}-\mathrm{CN}$ & -0.32398 & -0.14328 & 0.1807 & I-NO2 & -0.31738 & -0.15913 & 0.15825 \\
\hline $\mathrm{I}-\mathrm{H}$ & -0.29958 & -0.14351 & 0.15607 & I-ONO2 & -0.31088 & -0.14444 & 0.16644 \\
\hline I-N3 & -0.30959 & -0.15264 & 0.15695 & & & & \\
\hline
\end{tabular}


compounds. Obviously, the substituent of $-\mathrm{NH}_{2}$ or $-\mathrm{CH}_{3}$ group makes the $\mathrm{E}_{\text {Hомо }}$ and $\mathrm{E}_{\mathrm{LUMO}}$ increase. Whereas the substituent of $-\mathrm{CN},-\mathrm{CF}_{3},-\mathrm{N}_{3},-\mathrm{NF}_{2},-\mathrm{NO}_{2}$ or $-\mathrm{ONO}_{2}$ group makes the $\mathrm{E}_{\mathrm{HOMO}}$ and $\mathrm{E}_{\mathrm{LUMO}}$ decrease.

From table 4, it is also noted that some of the derivatives increase the HOMO-LUMO gaps of the parent compound, while other ones decrease these. For A, B and $\mathrm{G}$ series, the substituent group decreases the HOMO-LUMO gap when compared with the parent compounds A-H, B-H and G-H, respectively. For I series, the substituent group increases the HOMOLUMO gap when compared with the parent compound I-H. For C, D, E, F and H series, the substituent of some groups increases the HOMO-LUMO gap, whereas incorporation of other groups decreases the HOMO-LUMO gap. In addition, F series have higher HOMO-LUMO gap than other series. Thus, it may be inferred that $\mathrm{F}$ series have the lowest reactivity among these series.

\section{Conclusions}

In this work, the heats of formation, electronic structure, detonation properties of a series of ditetrazole derivatives with different substituent groups were studied by using the DFT-B3LYP method. The results show the HOFs of the title compounds are drastically influenced by substituents. The HOF is the biggest for E$\mathrm{N}_{3}$ and the smallest for $\mathrm{A}-\mathrm{CF}_{3}$. It is noted that all the series combined with $-\mathrm{NF}_{2}$ group except $\mathrm{B}-\mathrm{NF}_{2}$ all have higher densities, larger $\mathrm{D}$ and $\mathrm{P}$. Especially F$\mathrm{NF}_{2}$ has the largest detonation velocity and pressure among these derivatives. This shows that $-\mathrm{NF}_{2}$ group is an effective structural unit for increasing the detonation performance of the studied compounds. Calculation of $\triangle \mathrm{E}_{\mathrm{LUMO}-\mathrm{HOMO}}$ shows that $\mathrm{F}$ series have higher HOMOLUMO gap than other series, which indicated that $\mathrm{F}$ series has the lowest reactivity among these series.

\section{Acknowledgements}

We thank the National Natural Science Foundation of China (Grant U1304111), China Postdoctoral Science Foundation (No. 2013M531361) and Jiangsu Planned Projects for Postdoctoral Research Funds (No. 1201015B) for their support to this work.

\section{References}

1. Huynh M H V, Hiskey M A, Pollard C J, Montoya D P, Hartline E L and Gilardi R D 2004 J. Energ. Mater. 22 217
2. Huynh M H V, Hiskey M A, Chavez D E, Naud D L and Gilardi R D 2005 J. Am. Chem. Soc. 12712537

3. Gutowski K E, Rogers R D and Dixon D A 2007 J. Phys. Chem. B. 1114788

4. Talawar M B, Sivabalan R, Senthilkumar N, Prabhu G and Asthana S N 2004 J. Hazard. Mater. 11311

5. Chavez D E, Hiskey M A and Gilardi R D 2000 Angew. Chem. Int. Ed. 391791

6. Kerth J and Lobbecke S 2002 Propellants Explos. Pyrotech. 27111

7. Neutz J, Grosshardt O, Schaufele S, Schuppler H and Schweikert W 2003 Propellants Explos. Pyrotech. 28 181

8. Huynh M H V, Hiskey M A, Hartline E L, Montoya D P and Gilardi R D 2004 Angew. Chem. Int. Ed. 434924

9. Churakov A M, Smirnov O Y, Ioffe S L, Strelenko Y A and Tartakovsky V A 2002 Eur. J. Org. Chem. 142342

10. Joo Y H, Gao H X, Zhang Y Q and Shreeve J M 2010 Inorg. Chem. 493282

11. Guo Y, Tao G H, Zeng Z, Gao H X, Parrish D A and Shreeve J M 2010 Chem. Eur. J. 163753

12. Klapötke T M and Stierstorfer J 2009 J. Am. Chem. Soc. 1311122

13. Joo Y B and Shreeve J M 2009 Angew. Chem. Int. Ed. 48564

14. Li X H, Zhang R Z and Zhang X Z 2013 Struct. Chem. 24393

15. Li X H, Zhang R Z and Zhang X Z 2011 Struct. Chem. 224577

16. Zhang R Z, Li X H and Zhang X Z 2012 J. Chem. Sci. 124995

17. Alexander D, Thomas Klapke $\mathrm{M}$ and Franz Martin A 2011 Z. Anorg. Allg. Chem. 6371181

18. Ravi P, Girish Gore M, Surya Tewari P and Arun Sikder K 2012 Propellants Explos. Pyrotech. 3752

19. Zhang C, Zhu W and Xiao H 2011 Comput. Theor. Chem. 967257

20. Joo Y H and Shreeve J M 2009 Angew. Chem. Int. Ed. 48564

21. Wei T, Wu J, Zhu W, Zhang C and Xiao H 2012 J. Mol. Model. 183467

22. Zhang X, Zhu W and Xiao H 2010 J. Phys. Chem. A. 114603

23. Becke D 1992 J. Chem. Phys. 979173

24. Hariharan P C and Pople J A 1973 Theor. Chim. Acta. 28213

25. Li X H, Zhang R Z and Zhang X Z 2010 J. Hazard. Mater. 183622

26. Li X H, Cheng Q D and Zhang X Z 2010 J. Energ. Mater. 28251

27. Xu X J, Xiao H M, Ju X H, Gong X D and Zhu W H 2006 J. Phys. Chem. A. 1105929

28. Frisch M J, Trucks G W, Schlegel H B, Scuseria G E, Robb M A, Cheeseman J R, Zakrzewski V G, Montgomery J A, Stratmann R E, Burant J C, Dapprich S, Millam J. M, Daniels A. D, Kudin K N, Strain M. C, Farkas O, Tomasi J, Barone V, Cossi M, Cammi R, Mennucci B, Pomelli C, Adamo C, Clifford S, Ochterski J, Petersson G A, Ayala P Y, Cui Q, Morokuma K, Malick D K, Rabuck A D, Raghavachari K, Foresman J B, Cioslowski J, Ortiz J V, Baboul A G, Stefanov B B, Liu G, Liashenko A, Piskorz P, Komaromi I, Gomperts R, Martin R L, Fox D J, Keith T, Al- Laham M A, Peng 
C Y, Nanayakkara A, Gonzalez C, Challacombe M, Gill P M W, Johnson B, Chen W, Wong M W, Andres J L, Gonzalez C, Head Gordon M, Replogle E S and Pople J A 2003 GAUSSIAN 03, Revision B.02, Gaussian Inc.: Pittsburgh PA

29. Hehre W J, Radom L and Schleyer P V R 1986 In $A b$ Initio molecular orbital theory (New York: Wiley) p 124

30. Rice B M, Sahu S and Owens F J 2002 J. Mol. Struct. Theochem $\mathbf{5 8 3} 69$

31. Kamlet M J and Jacobs S J 1968 J. Chem. Phys. 4823

32. Zhang X H and Yun Z H 1989 In Explosive Chemistry (Beijing: National Defense Industry Press) p 198

33. Politzer P, Martinez J, Jane Murray S, Monica Concha C and Alejandro T 2009 Mol. Phys. 1072095

34. Lide DR 2004 In Handbook of chemistry and physics, 84th edn. (Boca Raton: CRC Press LLC) p 54

35. NIST Standard Reference Data Base Number 69, (http:// webbook.nist.gov/chemistry)
36. Balepin A A, Lebedev V P, Miroshnichenko E A, Koldobskii G I, Ostovskii V A, Larionov B P, Gidaspov B V and Lebedev Yu A 1977 Svoistva Veshchestv Str Mol. 293

37. Li X H, Tang Z X, Zhang X Z and Yang X D $2009 \mathrm{~J}$. Hazard. Mater. 165372

38. Li X H, Yin G X and Zhang X Z 2012 Chinese J. Chem. Phys. 25545

39. Li X H, Fu Z M and Zhang X Z 2012 Struct Chem. 23 515

40. Li X H, Zhang R Z and Zhang X Z 2010 J. Hazard. Mater. 183622

41. Talawar M B, Sivabalan R, Mukundan T, Muthurajan H, Sikder A K, Gandhe B R and Rao A S 2009 J. Hazard. Mater. 161589

42. Gilardi R, Flippen-Anderson J L and Evans R 2002 Acta Crystallogr. $\mathbf{E 5 8}$ o972

43. Fleming I 1976 In Frontier orbitals and organic chemical reactions (New York: John Wiley and Sons) p 157 